\title{
NEGARA HUKUM DAN POLITIK HUKUM ISLAM DI INDONESIA: CATATAN KRITIS ATAS PEMIKIRAN NURCHOLISH MADJID
}

\author{
Undang Hidayat \\ Sekolah Tinggi Agama Islam Al-Musaddadiyah Garut \\ E-mail: undang.hidayat@yahoo.com
}

\begin{abstract}
Many muslim scholars believed that the idea and model of legal state had exsited since the first hijriya Islamic century ago, when the prophet of Muhammad SAW declared Madina State, including with all instruments and its requirement of the state such as territory, constitution, society, and declaration. This view is also admitted by the Western Scholars who stated that the Prophet of Muhammad SAW had successfully implemented the bases of political authority and the model of the strongly modern state with the spirit of democracy in the past.
\end{abstract}

\begin{abstract}
Abstrak
Kebanyakan kalangan sarjana muslim meyakini bahwa gagasan dan model negara hokum sudah muncul sejak abad pertama Islam, tepatnya ketika Rasulullah SAW mendeklarasikan Negara Madinah, lengkap dengan semua instrumen dan telah terpenuhinya persyaratan bagi sebuah negara, yakni ada wilayah, konstitusi, masyarakat, dan pengakuan. Diakui pula oleh para sarjana Barat bahwa Nabi Muhammad SAW telah berhasil meletakan dasar-dasar kekuasaan politik dan model pemerintahan yang kuat dengan semangat demokrasi di zamannya.
\end{abstract}

Kata Kunci:

Negara Hukum, Politik Hukum, Hukum Islam, Trasformasi Hukum

\section{A. Pendahuluan}

Kebanyakan kalangan sarjana muslim meyakini bahwa gagasan dan model negara hokum sudah muncul sejak abad pertama Islam, tepatnya ketika Rasulullah SAW mendeklarasikan Negara Madinah, lengkap dengan semua instrumen dan telah terpenuhinya persyaratan bagi sebuah negara, yakni ada wilayah, konstitusi, masyarakat, dan pengakuan. Diakui pula oleh para sarjana Barat bahwa Nabi Muhammad SAW telah berhasil meletakan dasar-dasar kekuasaan politik dan model pemerintahan yang kuat dengan semangat demokrasi di zamannya.

Pengalaman sejarah di atas memberikan pengalaman berharga bagi semua bangsa di dunia untuk mereinterpretasikan kembali gagasan negara hokum dalam konteks kekinian yang berkolaborasi dengan semangat demokrasi dan pengakuan atas norma-norma universal hak asasi manusia. Namun bagi kebanyakan negara berpenduduk mayoritas muslim, usaha tersebut tidaklah mudah karena banyak berbenturan dengan tradisi dan lokalitas berlakunya hokum Islam.

Dalam beberapa aspek, aplikasi konsep negara hokum di sejumlah negara muslim banyak menemui kendala, terutama dalam menafsirkan kembali ajaran khilafah dalam tarik-ulur antara formalisme dan substansialisme serta demokrasi dan hak asasi manusia. Namun yang lebih keliru adalah menyalahkan syariah sebagai doktrin hokum yang dianggap tidak lagi relevan dengan kondisi kekinian dan dianggap tidak kompatibel dengan demokrasi dan hak asasi manusia. Untuk menjawab problematika di atas, penulis tertarik untuk mengkajinya lebih komprehensif dalam bentuk makalah yang difokuskan pada pembahasan tentang negara hukum dan politik hukum Islam di Indonesia sebagai catatan kritis atas pemikiran Nurcholish Madjid. 


\section{B. Gagasan Negara Hukum}

Negara hukum secara sederhana adalah negara yang penyelenggaraan kekuasaan pemerintahannya didasarkan atas hukum. Dalam negara hukum, kekuasaan menjalankan pemerintahan berdasarkan kedaulatan hukum (supremasi hukum) dan bertujuan untuk menjalankan ketertiban hukum. ${ }^{1}$ Pendapat lainnya menyebutkan bahwa dalam negara hukum, hukum sebagai dasar diwujudkan dalam peraturan perundang-undangan yang berpuncak pada konstitusi atau hukum dasar negara.

Dalam konstitusi negara tersebut harus memuat gagasan atau ide tentang konstitusionalisme, yaitu adanya pembatasan atas kekuasaan dan jaminan hak dasar warga negara. Dengan demikian dalam negara hukum, kekuasaan negara berdasar atas hukum, bukan kekuasaan belaka serta pemerintahan negara berdasar pada konstitusi yang berpaham konstitusionalisme, tanpa hal tersebut sulit disebut sebagai negara hukum. Menurut Jimly Asshiddiqie, ${ }^{2}$ supremasi hukum itu harus mencakup tiga ide dasar hukum, yakni keadilan, kemanfaatan, dan kepastian.

Dalam bingkai negara hukum, negara tidak boleh campur tangan terlalu banyak terhadap urusan dan kepentingan warga negara. Namun seiring perkembangan zaman, negara hukum formil berkembang menjadi negara hukum materiil yang berarti negara yang pemerintahannya memiliki keleluasaan untuk turut campur tangan dalam urusan warga dengan dasar bahwa pemerintah ikut bertanggung jawab terhadap kesejahteraan rakyat. Negara bersifat aktif dan mandiri dalam upaya membangun kesejahteraan rakyat.

Menurut Sobirin Malian, ${ }^{3}$ perkembangan konsep negara hukum merupakan produk

\footnotetext{
Mustafa Kamal Pasha sebagaimana dikutip oleh Dwi Winarno, Konsep Negara Hukum, artikel dalam http://prince-mienu.blogspot.com/2010/01/negara-hukum.html, diakses tanggal 12 November 2011.

2 Jimly Asshiddiqie, Konstitusi dan Konstitusionalisme Indonesia (Jakarta: Konstitusi Press. 2005), hlm. 35 .

Sobirin Malian, Gagasan Perlunya Konstitusi Baru Pengganti UUD 1945 (Yogyakarta: FH UII Press. 2001), hlm. 25.
}

dari sejarah, sebab rumusan atau pengertian negara hukum itu terus berkembang mengikuti sejarah perkembangan umat manusia. Seperti yang dijelaskan oleh A. Ahsin Thohari bahwa konsep negara hukum muncul sebagai respon dari pemikiran dan gagasan negara modern yang multi perspektif dan selalu aktual sesuai dengan perkembangan zaman. $^{4}$

Kemudian jika ditinjau dari perspektif historis perkembangan pemikiran filsafat hukum dan kenegaraan gagasan mengenai negara hukum sudah berkembang sejak 1800 SM. ${ }^{5}$ Namun akar terjauh mengenai perkembangan awal pemikiran negara hukum adalah pada masa Yunani Kuno, di mana gagasan kedaulatan rakyat tumbuh dan berkembang dari tradisi Romawi. Sedangkan tradisi Yunani Kuno menjadi sumber dari gagasan kedaulatan hukum. ${ }^{6}$

Munculnya pemikiran atau konsepsi manusia tentang negara hukum tampaknya sudah lahir dan berkembang seiring dengan perkembangan sejarah manusia. Ide negara hukum menurut Aristoteles ini, tampak sangat erat dengan "keadilan", bahkan suatu negara akan dikatakan sebagai negara hukum apabila suatu keadilan telah tercapai. Konstruksi seperti ini mengarah pada bentuk negara hukum dalam arti etis dan sempit, karena tujuan negara semata-mata mencapai keadilan. Teori-teori yang mengajarkan hal tersebut dinamakan teori-teori etis, sebab menurut teori ini isi hukum semata-mata harus ditentukan oleh kesadaran etnis kita mengenai apa yang adil dan apa yang tidak adil.?

Menurut Aristoteles, suatu negara yang baik ialah negara yang diperintah dengan konstitusi dan berkedaulatan hukum. Ada tiga unsur dari pemerintahan yang berkonstitusi yaitu: Pertama, pemerintahan dilaksanakan untuk kepentingan umum; Kedua,

4 A. Ahsin Thohari, Komisi Yudisial dan Reformasi Peradilan (Jakarta: Elsam. 2004), hlm. 48.

5 J. J. von Schmid, Pemikiran tentang Negara dan Hukum (Jakarta: Pembangunan. 1988), hlm. 7.

6 Jimly As-Shiddiqie, Gagasan Kedaulatan Rakyat dalam Konstitusi dan Pelaksanaannya di Indonesia (Jakarta: Ichtiar Baru van Hoeve. 1994), hlm. 11.

7 lbid. 
pemerintahan dilaksanakan menurut hukum yang berdasarkan pada ketentuan-ketentuan umum, bukan hukum yang dibuat secara sewenang-wenang yang menyampingkan konvensi dan konstitusi; dan Ketiga, pemerintahan berkonstitusi berarti pemerintah yang dilaksanakan atas kehendak rakyat, bukan berupa paksaan atau tekanan yang dilaksanakan pemerintahan yang berkuasa. Dalam kaitannya dengan konstitusi, Aristoteles yang mengemukakan bahwa konstitusi merupakan penyusunan jabatan dalam suatu negara dan menentukan apa yang dimaksudkan dengan badan pemerintahan dan apa akhir dari setiap masyarakat. Selain itu, konstitusi merupakan aturan-aturan dan penguasa harus mengatur negara menurut aturan-aturan tersebut. ${ }^{8}$

Konsep negara hukum yang dikembangkan oleh Plato dan Aristoteles lahir beberapa puluh tahun sebelum Masehi. Pada perkembangan berikutnya kelahiran konsep negara hukum sesudah masehi didasarkan pada sistem pemerintahan yang berkuasa pada waktu itu, seperti dikemukakan oleh beberapa ahli. Misalnya saja, Nicolo Machiavelli (1469-1527) seorang sejarawan dan ahli negara telah menulis bukunya yang terkenal "Il Prinsipe (The Prince)" tahun 1513.

Menurut S.F. Marbun, ${ }^{9}$ Machiavelli hidup pada masa intrik-intrik dan peperangan yang terus-menerus di Florence, di mana pada waktu tata kehidupan berbangsa dan bernegara tampaknya lebih mengutamakan kepentingan negara. Tata keamanan dan ketentraman, Di samping keagungan negara, harus merupakan tujuan negara, supaya Italia menjadi suatu negara nasional. Dalam usaha untuk mewujudkan cita-cita itu raja harus merasa dirinya tidak terikat oleh normanorma agama ataupun norma-norma akhlak. Raja juga dianjurkan agar jangan berjuang dengan mentaati hukum, raja hendaknya menggunakan kekuasaan dan kekerasan seperti halnya juga binatang.

Demikian halnya dengan penguasa, menurut Machiavelli, pimpinan negara haruslah

8 Ibid.

9 S. F. Marbun dkk, Dimensi-Dimensi Pemikiran Hukum Administrasi Negara (Yogyakarta: UII Press. 2001), hlm. 4. mempunyai sifat-sifat seperti kancil untuk mancari lubang jaring dan menjadi singa untuk mengejutkan serigala. Raja atau pimpinan negara harus memiliki sifat-sifat cerdik pandai dan licin ibarat seekor kancil, akan tetapi harus pula memiliki sifat-sifat yang kejam dan tangan besi ibarat seekor singa, seperti: A prince being thus obliged to know well how to act as a beast must imitate the fox and the lion, for the lion cannot protect himself from traps and the fox cannot defend himself from wolves. One must therefore be a fox to recognise traps, and a lion to frighten wolves. ${ }^{10}$ Demikian beberapa anjuran Machiavelli kepada raja untuk menerapkan kekuasaan absolut dalam negara. Maksudnya agar negara Italia menjadi negara besar yang berkuasa.

Sedangkan Jean Bodin (1530-1596) tampaknya menganjurkan absolutisme raja. Raja harus mempunyai hak mutlak membuat undang-undang bagi rakyatnya yang diperintah. Kedaulatan itu puissance absolute atau kekuasaan mutlak yang terletak di dalam tangan raja dan tidak dibatasi oleh undangundang. Karena yang membuat undangundang itu raja, maka tidak mungkin pembuatnya diikat oleh buatannya sendiri. Akan tetapi yang berlawanan dengan Machiavelli adalah Jean Bodin mengatakan bahwa raja itu terikat dengan hukum alam. Lebih lanjut Jean Bodin memandang kekuasan yang terpusat pada negara yang makin lama makin tegas tampak dalam bentuk kekuasaan raja. Karena itu dirumuskan bahwa dasar pemerintah absolut terletak dalam kedaulatan, yaitu kekuasaan raja yang superior. ${ }^{11}$

Adapun Thomas Hobbes (1588-1679) penganut ajaran hukum alam - berpendapat bahwa manusia sebelum hidup dalam lingkungan sosial masyarakat bernegara, hidup dalam alami. Dalam keadaan alami itu manusia mempunyai hak alami yang utama, yaitu hak utama mempertahankan diri sen-

10 Peneliti mengutip penjelasan Luigi Ricci dan E.R.P. Vincent, A Mentor Book, The New Amer Oan Library: Cristian Gans - A Mentor book (USA: The New American Library. 1955), hlm. 101 dan R. Kranenburg, Ilmu Negara Umum, Terjemah: Tb. Sabaroedin (Jakarta: J.B. Wolters-Groningen. 1955), hlm. 51.

${ }^{11}$ Theo Huijber, Filsafat Hukum dalam Lintasan Sejarah (Yogyakarta: Kanisius. 1995), hlm. 57. 
diri. Dalam situasi demikian itu manusia merupakan musuh bagi manusia lainnya dan siap saling menerka seperti serigala, akibatnya ialah merajalelanya peperangan semuanya melawan semuanya. Namun, ia harus dibimbing oleh akalnya manusia agar dapat mengerti bahwa apabila keadaan yang demikian itu diteruskan, maka semuanya akan binasa.

Oleh karena itu, manusia lalu bergabung memilih penguasa yang menjamin hukum melalui suatu perjanjian sosial. Dalam teori Hobbes, perjanjian masyarakat tidak dipakai untuk membangun masyarakat (civitas) melainkan untuk membentuk kekuasaan yang diserahkan kepada raja. Raja bukan menerima kekuasan dari masyarakat melainkan ia memperoleh wewenang dan kuasanya kepada raja, maka kekuasaan raja itu mutlak. ${ }^{12}$

Pendapat yang dikemukakan beberapa ahli di atas menunjukkan sebagian mereka berpandangan ekstrim, yakni untuk membenarkan sistem pemerintahan yang bersifat absolut guna diterapkan dalam kehidupan bernegara. Memang apabila ditelusuri lebih jauh pandangan ini, tentu akan terlihat bahwa konsepsi mereka dilatarbelakangi oleh adanya situasi negara yang buruk di masa mereka hidup. Sehingga bagi mereka, negara atau penguasa yang kuat diperlukan untuk mengatasi peperangan yang terjadi waktu itu.

Perlawanan terhadap kekuasaan yang mutlak dari raja secara konkret yang dilaksanakan dengan memperjuangkan sistem konstitusional, yaitu sistem pemerintahan yang berdasarkan konstitusi. Pemerintahan tidak dibolehkan dikendalikan menurut kehendak raja saja, melainkan harus didasarkan pada hukum konstitusi. John Locke (1632-1704) mengemukakan, kekuasaan raja harus dibatasi oleh suatu leges fundamentalis. Namun yang perlu dicatat adalah perjuangan konstitusional yang membatasi kekuasaan raja banyak dipengaruhi oleh berbagai perkembangan, di antaranya: Pertama, reformasi; Kedua, renaissance; Ketiga, hukum kodrat; dan Keempat, timbulnya kaum bourgeoisi beserta aliran pencerahan akal (aufklarung). ${ }^{13}$

12 Ibid.

13 Ibid.
Seiring dengan berkembang zaman dan tuntutan masayarakat pada waktu, lahir pula gagasan atau pemikiran untuk melindungi hak asasi manusia yang dipelopori oleh pemikir-pemikir Inggris dan Prancis yang sangat mempengaruhi tumbangnya absolutisme dan lahirnya negara hukum. Sementara di Inggris, perlawanan masyarakat terhadap negara (monarchi absolutis) telah lama berjalan (sebelum John Locke menuliskan teorinya tentang negara dan hukum dalam buku Two Treatises of Civil Government (1690) ${ }^{14}$ menggambarkan pertikaian terus- menerus antara King dan Parliament, yang melahirkan piagam-piagam di mana diakui hak-hak asasi bangsa Inggris, yaitu: Pertama, Magna Charta (1215); Kedua, Petition of Rights (1628); Ketiga, Habeas Corpus Act (1679); dan Keempat, Bill of Rights (1689). ${ }^{15}$

Di Prancis, dipelopori antara lain Charles Louis de Scondat, Baron de La Brede et de La Montesquieu (1688-1775) dan Jean Jacques Rousseau (1746-1827), Renaissance dan Reformasi berkembang dengan baik. Perjuangan hak-hak asasi manusia di Perancis itu memuncak dalam revolusi Perancis pada tahun 1789, yang berhasil menetapkan hak-hak asasi manusia dalam Declaration des Droits de l'homme et du Citoyen, yang pada tahun itu ditetapkan oleh Assemblee National Prancis, dan pada tahun-tahun berikutnya dimasukkan ke dalam Constitution. Sedangkan di Amerika Serikat sebelumnya, yaitu pada tanggal 4 Juli 1776 sudah dirumuskan dalam Declaration of Independence. Dengan adanya perlindungan terhadap hak asasi manusia, maka kekuasaan absolut dari raja lama kela-

14 John Locke dalam karyanya, Two Treatises of Civil Government, banyak menjelaskan tentang pola hubungan kekuasaan raja dan rakyat dalam bingkai negara hukum dengan tidak menitikberatkan pada kekuasaannya, tetapi lebih pada proses pengambilan keputusan di bidang politik dan hukum. Artinya, ia tetap mendukung sistem pemerintahan parlementer dalam sistem pemerintahan monarki konstitusional Inggris, tapi pengambilan keputusan dilakukan melalui konsensus antara raja, perdana menteri, dan anggota parlemen. Ibid. hlm. 79-83.

15 Pada umumnya kemenangan ada di pihak masyarakat, monarki absolut tidak dapat berkembang, sedangkan parlemen langkah demi langkah membesarkan pengaruhnya. Dalam karya Locke muncul beberapa prinsip hukum yang berlaku dalam negara hukum modern, yakni asas yang ada hubungannya dengan organisasi negara hukum. Ibid. hlm. 83-86. 
maan semakin susut dan bersama-sama dengan itu kebutuhan akan negara hukum makin mantap. ${ }^{16}$

Pada babak sejarah kini, sulit untuk membayangkan negara tidak sebagai negara hukum. Setiap negara yang tidak mau dikucilkan dari pergaulan masyarakat internasional menjelang abad ke-21 setidaknya secara formal akan memaklumkan dirinya sebagai negara hukum. Menurut Budiono Kusumohamidjojo, ${ }^{17}$ dalam negara hukum, hukum menjadi aturan permainan untuk mencapai citacita bersama sebagai kesepakatan politik. Hukum juga menjadi aturan permainan untuk menyelesaikan segala macam perselisihan, termasuk juga perselisihan politik dalam rangka mencapai kesepakatan politik tadi. Dengan demikian, hukum tidak mengabdi kepada kepentingan politik sektarian dan primordial melainkan kepada cita-cita politik dalam kerangka kenegaraan.

\section{Negara Hukum dan Masyarakat Madani}

Dalam pemikiran politik hukum Islam, negaralah yang bertanggungjawab terhadap urusan masyarakat. Negara dalam perspektif Islam bukanlah sekedar alat untuk menjamin dan menjaga kemaslahatan individu saja sebagaimana halnya liberalisme-kapitalisme akan tetapi merupakan suatu institusi yang mengurusi kebutuhan individu, organisasi (jama'ah), dan masyarakat sebagai satu kesatuan, baik urusan dalam maupun luar negerinya, sesuai dengan peraturan tertentu yang membatasi hak dan kewajiban masingmasing. Sebagaimana yang dinyatakan oleh Bernard Lewis, bahwa sejak zaman Nabi Muhammad SAW, umat Islam merupakan entitas politik dan agama sekaligus, dengan Muhammad sebagai kepala negara.

Untuk memahami term masyarakat madani, Cak Nur mendeskripsikannya dalam perspektif ke-Indonesiaan yang aspiratif, substantif dan fungsional. Cak Nur menafsirkan bahwa wujud nyata masyarakat madani termanifestasi ketika Nabi SAW hijrah ke

16 Ibid. hlm. 87-93.

17 Budiono Kusumohamidjojo, Filsafat Hukum: Problemtika Ketertiban yang Adil (Jakarta: Grasindo. 2004), hlm. 36-37.
Yatsrib. ${ }^{18}$ Dengan tindakan itu, Nabi SAW telah merintis dan memberi teladan kepada ummat manusia dalam membangun masyarakat madani, yaitu masyarakat yang berperadaban (ber-madâniyyah) karena tunduk dan patuh pada (dâna-yadînu) kepada ajaran kepatuhan (dîn). Masyarakat madani hakikatnya adalah reformasi total terhadap masyarakat tak kenal hukum (lawness) Arab jahiliyah dan terhadap supremasi kekuasaan pribadi seorang penguasa yang selama ini menjadi pengertian umum tentang negara. ${ }^{19}$

Cak Nur menandaskan bahwa Madinah adalah sebuah konsep pola kehidupan sosial yang sopan, yang ditegakkan atas dasar kewajiban dan kesadaran umum untuk patuh kepada peraturan dan hukum. Karena itu kata Arab untuk peradaban adalah madâniyyah memiliki dasar pengertian yang sama dengan term dari akar rumpun bahasa IndoEropa seperti civic, civil, polis dan politiae. Semua merujuk kepada pola kehidupan yang teratur dalam lingkungan masyarakat yang disebut "kota" (city, polis). Maka civil society atau masyarakat madani dapat diartikan sebagai masyarakat yang utuh (solid) dimana kemajemukan dan kebersamaan sangat dihormati. Sebagai konsep kemasyarakatan, semua negara dan bangsa di dunia pada dasarnya berbicara tentang masyarakat madani sesuai kepentingan masing-masing, namun secara kontekstual, masing-masing bangsa punya sistem nilai sebagai acuan filosofisnya. ${ }^{20}$

Kemudian dipertegas pula dengan pendapat Sufyanto bahwa perspektif masyarakat madani di Indonesia dapat dirumuskan secara sederhana, yaitu suatu upaya membangun masyarakat adil, terbuka dan demokratis, dengan landasan takwa kepada Allah dalam arti semangat Ketuhanan Yang Maha Esa. ${ }^{21}$ Upaya itu ditambah legalnya nilai-nilai hubungan sosial yang luhur, seperti toleransi

18 Nurcholish Madjid, Masyarakat Madani dan Investasi Demokrasi: Tantangan dan Kemungkinan (Bandung: Pustaka Hidayah. 1999), hlm. 17.

19 Nurcholish Madjid, Puasa Titian Menuju Rayyan (Yogyakarta: Pustaka Pelajar. 2000), hlm. 125.

20 Nurcholish Madjid, Agama dan Politik dalam Islam (Yogyakarta: Pustaka Pelajar. 2001), hlm. 52.

21 Sufyanto, Masyarakat Tamaddun (Yogyakarta: Pustaka Pelajar. 2001), hlm. 120. 
dan juga pluralisme, adalah merupakan kelanjutan nilai-nilai keadaban (tamaddun). Sebab toleransi dan pluralisme adalah wujud ikatan keadaban (bond of civility).

Bercermin dari sebuah pemahaman bahwa manusia adalah fitrah, maka Cak Nur mengutip hadits Nabi Muhammad SAW yang menyatakan bahwa: "sebaik-baik umat beragama di sisi Allah SWT adalah yang memiliki sifat al-hanafiyat al-samhah", yakni umat yang bersemangat mencari kebenaran yang lapang, toleran, tanpa kefanatikan. Menurut Cak Nur, hal ini sudah dipraktikan di masa awal Islam hakikat agama adalah mengajarkan keterbukaan atau toleransi. Toleransi yang dimaksud di sini adalah membangun suatu pandangan yang relatif inklusif dan menjauhkan diri dari ke truth claim yang eklusif.22

Berdasarkan uraian di atas, penulis merumuskan bahwa Cak Nur tidak memberikan definisi khusus tentang negara hukum. Namun ia menyandarkan gagasan tersebut kepada fakta historis mengenai keterkaitan antara konsep civil society dengan masyarakat madani. Menurut Cak Nur, keduanya tidak memiliki hubungan sama sekali. Masyarakat madani bermula dari sejarah perjuangan Nabi Muhammad SAW dalam menghadapi kondisi jahiliyyah masyarakat Arab Quraisy di Mekkah. Nabi memperjuangkan kedaulatan negara Madinah, agar seluruh kelompok masyarakat di Madinah terbebaskan (terjamin semua hak-haknya) serta umatnya (muslim) memiliki keleluasaan dalam menjalankan syariat Islam di bawah suatu perlindungan hukum yang disepakati bersama (ijmâ' fîal-siyâsî).

\section{Negara Hukum dan Masa Depan Politik Hukum Islam di Indonesia}

Menjelaskan negara hukum juga tidak terlepas dari pembahasan tentang masa depan politik hukum Islam di Indonesia. Masa depan politik hukum Islam yang dimaksud merupakan bagian penting yang erat kaitannya dengan perjuangan umat Islam untuk menegakkan reformasi syariah dan demok-

22 Nurcholish Madjid, Dialog Keterbukaan: Artikulasi Nilai Islam dalam Wacana Sosial Politik Kontemporer (Jakarta: Paramadina. 1998), hlm. 254. rasi di Indonesia. Hal tersebut masih membutuhkan usaha-usaha yang lebih keras, karena hendaknya mempertimbangkan dimensi sosial, politik, dan budaya.

Bahkan hal ini telah ditunjukkan oleh Cak Nur melalui pemikiran-pemikirannya, yakni bagi masyarakat Indonesia yang sangat majemuk, reformasi hukum mesti sejalan dengan proses demokratisasi di Indonesia. Menurutnya reformasi hukum mesti ditopang oleh niat yang tulus, sebab ia akan senantiasa berada dalam konsensus dan konflik di antara kelompok-kelompok yang berkepentingan.

Cak Nur mendukung pandangan bahwa Pancasila dan Undang-Undang Dasar 1945 sebagai pedoman kehidupan bernegara mesti betul-betul menjadi substansi demokratisasi. la beralasan bahwa dengan demokrasi, Indonesia akan mempunyai tujuan yang jelas, yaitu tercapai cita-cita bangsa yang termuat dalam Pancasila dan UndangUndang Dasar 1945. la juga menegaskan bahwa demokrasi mesti menjadi cara hidup (way of life) masyarakat Indonesia. Pendapat ini memberi harapan bahwa untuk mewujudkan cita-cita Pancasila dan Undang-Undang Dasar 1945, masyarakat Indonesia hendaknya bergerak di dalam koridor yang tepat, menghargai pluralitas, serta menghargai kebebasan dan hak-hak asasi manusia. Inilah yang Cak Nur sebut dengan demokrasi.

Untuk merespon pandangan Cak Nur di atas, peneliti ingin mengajukan pertanyaan, yaitu bagaimana reformasi syariah bisa sejalan dengan tujuan negara hukum dan demokrasi di Indonesia. Menurut hemat peneliti sendiri, Cak Nur tampaknya telah mempertimbangkan dengan cermat bahwa Indonesia adalah negara hukum berdasarkan Pancasila. Sebagai pandangan hidup bangsa Indonesia, Pancasila menurutnya lebih dari sekedar cita-cita ideal untuk mempertemukan semua perbedaan dalam kemajemukkan, tetapi juga jawaban yang paling realistis atas dinamika politik hukum yang telah berlangsung sejak awal kemerdekaan Indonesia.

Cak Nur tampaknya juga tidak ingin menolak pandangan di kalangan ahli hukum tata negara bahwa negara berdasarkan hukum ditandai oleh beberapa asas, antara lain asas legalitas (legaliteits beginsel) dalam 
proses penegakan hukum. Menurut Cak Nur, asas ini mengandung makna bahwa dalam negara hukum semua perbuatan atau tindakan pemerintahan atau negara harus didasarkan pada ketentuan hukum tertentu yang sudah ada sebelum perbuatan atau tindakan itu dilakukan. Selain itu, dalam negara hukum tidak dibenarkan adanya campur tangan seseorang atau kelompok atas hak dan kebebasan orang atau kelompok masyarakat lainnya. Penegakan hukum menurut Cak Nur hanya dapat dilakukan berdasarkan aturanaturan hukum tertentu berdasarkan asas persamaan di depan hukum, yang lazim disebut equality before the law.

Untuk memungkinkan kepastian perwujudan asas legalitas dan persamaan di depan hukum ini, instrumen hukum harus dibuat mengacu kepada hukum tertinggi (konstitusi) dan bukan berdasarkan kehendak perorangan atau kelompok tertentu. Menurut Cak Nur, berbagai peraturan hukum yang dibuat dalam bentuk peraturan perundangundangan tidak boleh dibuat untuk kepentingan perorangan atau kelompok, tetapi untuk tujuan penegakan hukum itu sendiri (supremacy of law). Alasan utama yang ingin diajukan oleh Cak Nur adalah untuk menghindari peraturan perundang-undangan bagi kepentingan penguasa, yang pada akhirnya akan membentuk kekuasaan tirani yang jelas-jelas bertentangan dengan prinsip demokrasi.

Ide dasar negara hukum Indonesia, menurut Cak Nur tidak terlepas dari ide dasar tentang rechtsstaats. Pendapat Cak Nur tampak relevan dengan yang dijelaskan oleh Hadjon bahwa Indonesia merupakan negara yang mewarisi hukum Belanda yang menganut negara hukum (rechtsstaats). ${ }^{23}$ Hadjon menjelaskan bahwa konsep Negara Kesatuan Republik Indonesia awalnya diperkenalkan oleh Soepomo dalam pidatonya di depan Sidang BPUPKI pada tanggal 31 Mei 1945. NKRI yang dijelaskan oleh Soepomo di awal

23 Philipus M. Hadjon, Perlindungan Hukum Bagi Rakyat di Indonesia: Sebuah Studi Tentang Prinsipprinsipnya, Penerapannya oleh Pengadilan Dalam Lingkungan Peradilan Umum dan Pembentukan Peradilan Administrasi Negara (Surabaya: Bina Ilmu. 1972), hlm. 72-73. kemerdekaan mengadopsi sistem pemisahan kekuasaan dalam bentuk kelembagaan MPR/DPR sebagai lembaga tertinggi sebagai pelaksana kedaulatan rakyat secara penuh. ${ }^{24}$

Syarat-syarat dasar rechtsstaat yang dikemukakan Cak Nur erat kaitannya dengan pandangan Burkens dalam tulisannya tentang ide negara hukum dalam sistem ketatanegaraan Indonesia yang menjelaskan sebagai berikut: ${ }^{25}$

1. Asas legalitas);

2. Pembagian kekuasaan;

3. Hak-hak dasar (grondrechten); dan

4. Pengawasan peradilan, bagi rakyat tersedia saluran melalui pengadilan yang bebas untuk menguji keabsahan tindakan pemerintah (rechtmatigeidstoetsing).

Sebagai hukum dasar tertulis, UndangUndang Dasar 1945 hanya memuat dan mengatur hal-hal yang prinsip dan garis-garis besar saja. Negara Indonesia sebagai negara hukum dapat diketahui dalam: ${ }^{26}$

1. Bab I Pasal 1 ayat (3) Undang-Undang Dasar 1945, Negara Indonesia adalah negara hukum;

2. Pembukaan dicantumkan kata-kata: Pemerintah Negara Indonesia yang melindungi segenap bangsa Indonesia, dan seluruh tumpah darah Indonesia;

3. Bab X Pasal 27 ayat (1) disebutkan segala warga negara bersamaan kedudukannya di dalam hukum pemerintahan dan wajib menjunjung hukum dan itu dengan dengan tidak ada kecualinya;

4. Penjelasan Undang-Undang Dasar 1945 (yang sudah dihapus) disebutkan dalam Sistem Pemerintahan Negara, yang mak-

24 Pasal 1 ayat (2) UUD 1945 Pra-Amandemen menjelaskan bahwa: "Kedaulatan berada di tangan rakyat, dan dilakukan sepenuhnya oleh Majelis Permusyawaratan Rakyat". Pasal ini mensuratkan bahwa kedaulatan negara ini ada ditangan rakyat dan yang mempunyai wewenang penuh untuk melaksanakan kedaulatan rakyat tersebut adalah MPR. Konsep ini yang menjadi fakta bahwa sebelum amademen, UUD 1945 menggunakan asas supremasi parlemen pusat.

25 Peneliti mengutip pemikiran Burkens, Ide $\mathrm{Ne}$ gara Hukum dalam Sistem Ketatanegaraan Indonesia, sebagaimana dikutip pula oleh Philipus M. Hadjon, Perlindungan Hukum. hlm. 72-73.

26 S.F. Marbun, Dimensi-dimensi Pemikiran Hukum Administrasi Negara (Yogyakarta: UII Press. 2001), hlm. 17-20. 
nanya tetap bisa dipakai, yaitu Indonesia ialah negara yang berdasar atas hukum (rechtstaat), tidak berdasarkan atas kekuasaan belaka (machtstaat);

5. Sumpah/Janji Presiden/Wakil Presiden ada kata-kata "memegang teguh UndangUndang Dasar dan segala undang-undang dan peraturannya dengan selurus-lurusnya";

6. Bab XA Hak Asasi Manusia Pasal 28i ayat (5), disebutkan bahwa "Untuk penegakkan dan melindungi hak asasi manusia sesuai dengan prinsip negara hukum yang demokratis, maka pelaksanaan hak asasi manusia dijamin, diatur dan dituangkan dalam Peraturan Perundang-undangan;

7. Sistem hukum yang bersifat nasional;

8. Hukum dasar yang tertulis (konstitusi), hukum dasar tidak tertulis (konvensi);

9. Tap MPR Nomor: III/MPR/2000 tentang Sumber Hukum dan Tata Urutan Peraturan Perundang-undangan; dan

10. Adanya peradilan bebas.

Selain itu, keberadaan Dewan Perwakilan Rakyat (DPRD) di daerah pun harus tunduk pada majelis tertinggi. DPRD tidak punya kekuasaan untuk membuat kebijakannya sendiri. Kebijakan yang dijalankan haruslah berasal dari pemerintah pusat. Jika diamati, konsep ini lebih menekankan UndangUndang Dasar 1945 sebagai landasan konstitusional tertinggi yang tidak mengenal adanya legal autnonomy. Tapi sekaligus membuka peluang bagi penguasa untuk berkuasa penuh dan tidak menerapkan demokrasi murni atas nama konstitusi itu sendiri. Sebagai contoh, pada masa Orde Lama dan Orde Baru, Indonesia nyaris tidak menerapkan negara hukum secara murni (seutuhnya). Fakta sejarah menunjukkan bahwa MPR/DPR pernah mendaulat Soekarno sebagai "Presiden Seumur Hidup" di era demokrasi terpimpin dan Presiden Soeharto pernah berkuasa hampir 32 tahun berkuasa (1966-1998).

Pengalaman sejarah di atas hanyalah sebagian contoh, di mana prinsip supremacy of law dalam bingkai negara hukum Indonesia tidak dijalankan secara murni. Kekuasaan berada penuh di tangan Presiden, yang terjadi bukanlah hukum yang menjadi kekuasaan tertinggi, tetapi Presidenlah yang menjadi penguasa tunggal. Presiden begitu tidak terbatas menjadi penguasa dominan, sedangkan legislatif dan yudikatif hanya menjadi pelengkap sistem kekuasaan atas nama demokrasi. Akibatnya prinsip the rule of law tidak berjalan sebagaimana mestinya - dan yang muncul adanya kekuasaan tirani.

Kekuasaan tirani jelas bertentangan dengan asas persamaan di depan hukum (equality before the law). Di masa Orde Baru khususnya, para pejabat negara banyak melakukan korupsi, kolusi dan nepotisme nyaris tidak bisa dijerat dengan hukum. Mereka aman berlindung dibawah tirani penguasa tunggal. Jerat hukum hanya bisa menjangkau kepada yang siapa saja yang mereka sebut dengan "pembangkang". UndangUndang Subversif di masa Orde Baru sedemikian massive telah membungkam siapapun yang berani menentang kekuasaan Orde Baru. Akhirnya, asas equality before the law hanya menjadi slogan demokrasi semu di masa kekuasaan rezim Orde Baru.

Demikian halnya dengan asas legalitas (due process of law) cenderung sangat diskriminatif. Penguasa di masa Orde Baru telah menggunakan pasal-pasal penyebar kebencian, Pasal 154, 154a, 155, 156, 156a, 157, dan 160 KUHP (hartzai artikelen), sebagai alat untuk membungkam aktivis pro-demokrasi. Tindakan subversif adalah alasan yang paling sering ditujukan kepada mereka yang menanyakan keadilan, demokrasi dan semacamnya secara terang-terangan. Sejarah telah mencatat terjadinya berbagai tindak penculikan dan penangkapan terhadap para aktivis pro demokrasi, dipenjara sebagai tahanan politik (tapol), dan penerapan operasi militer untuk menumpas berbagai kelompok yang dianggap dapat mengganggu stabilitas politik Orde Baru.

Angin segar demokrasi mulai berubah pasca-amandemen Undang-Undang Dasar 1945 di era reformasi $1998 .{ }^{27}$ Cak Nur ber-

27 Dalam penyelenggaraan negara Indonesia sebagai negara hukum telah dikembangkan konsep checks and balances, seperti adanya Peradilan Tata Usaha Negara. Hal lain sebagaimana dalam konsiderans Tap MPR Nomor: XI/MPR/1998, tentang Penyelenggaraan Negara yang Bersih dan Bebas dari Korupsi, Kolusi dan Nepotisme, huruf a, yaitu: "Pelaksanaan 
sama kalangan pro demokrasi memandang bahwa konstitusi bukanlah sesuatu yang baku dan tidak bias diubah. Dinamika politik hukum di era reformasi telah berhasil mendorong dilakukannya perubahan pada beberapa pasal. Misalnya Pasal 1 ayat (2) UndangUndang Dasar 1945: "Kedaulatan adalah di tangan rakyat, dan dilakukan sepenuhnya oleh Majelis Permusyawaratn Rakyat", diubah menjadi "Kedaulatan berada di tangan rakyat dan dilaksanakan sepenuhnya menurut Undang-Undang Dasar".

Demikian halnya setelah dikeluarkannya Ketetapan MPR Nomor: XI/ MPR/1998, Indonesia berupaya mewujudkan negara hukum yang berorientasi pada good governance. Upaya itu dilakukan melalui penetapan Undang-undang Nomor 28 Tahun 1999 tentang Penyelenggaraan Negara yang Bersih dan Bebas dari Korupsi, Kolusi dan Nepotisme. Menurut Undang-Undang ini, di dalam negara hukum di dalam penyelenggaraan negara harus mengacu pada asas umum penyelenggaraan negara, yaitu: ${ }^{28}$

1. Asas Kepastian Hukum;

2. Asas Kepentingan Umum;

3. Asas Keterbukaan;

4. Asas Proporsionalitas;

5. Asas Profesionalitas; dan

6. Asas Akuntabilitas.

Indonesia sebagai negara hukum segala sesuatu harus berdasarkan kepada hukum, yang diimplementasikan dalam peraturan perundang-undangan ${ }^{29}$ yang ada sebagai ma-

penyelenggaraan negara oleh lembaga-lembaga eksekutif, yudikatif dan eksekutif. Selain itu juga telah dikembangkan lembaga-lembaga ekstra struktural baik yang dibentuk berdasarkan Undang-undang maupun dengan Keputusan (Peraturan) Presiden tentang lembaga-lembaga yang bertugas untuk mengawasi jalannya pemerintahan, seperti Mahkamah Konstitusi, Komisi Pemeriksa Korupsi, Komisi Ombudsman dan sebagainya.

28 Prajudi Atmosudirjo, Hukum Administrasi Negara (Jakarta: Ghalia Indonesia. 1995), hlm. 23-25 dan Moh. Kusnardi, dan Harmaily Ibrahim, Pengantar Hukum Tata Negara Indonesia (Jakarta: PSHTN FH UI dan Sinar Bakti. 1988), hlm. 107-110.

29 Peraturan perundang-undangan yang dimaksud peneliti di sini adalah setiap keputusan dalam bentuk tertulis yang dikeluarkan dan ditetapkan oleh pejabat berwenang dan mengikat umum (mencakup undang-undang dalam arti formal maupun material). Hukum tertulis diartikan sebagai setiap keputusan dalam bentuk tertulis oleh pejabat yang berwenang. nifestasi dari hukum positif, dan dalam rangka penegakan hukum telah dibentuk berbagai lembaga peradilan sebagai upaya untuk memberikan kepastian hukum dan perlindungan hak-hak setiap warga negara Indonesia. ${ }^{30}$

Cak Nur mendukung kalangan ahli hukum tata negara, yang mendorong Indonesia dikembalikan menjadi negara hukum seutuhnya melalui perubahan Pasal 1 ayat (1) Undang-Undang Dasar 1945. la mendukung NKRI hendaknya menjadikan hukum sebagai landasan konstitusional. ${ }^{31}$ Artinya, ketika Undang-Undang Dasar 1945 diamandemen sesuai dengan prinsip, asas, dan tujuan negara hukum, maka setiap penyelenggara kekuasaan negara haruslah didasarkan atas hukum (Undang-Undang Dasar 1945). ${ }^{32}$ la juga sangat mendukung pemajuan HAM dalam konstitusi yang diakomodir pada pasal 28, 28A, 28B, 28C, 28D, 28E, 28F, 28G, 28H, dan 28I Undang-Undang Dasar 1945 hasil amandemen. Dengan adanya pasal-pasal HAM tersebut, maka NKRI menjadi negara hukum yang menjamin pemenuhan HAM bagi semua orang.

Memasuki era reformasi, muncul tuntutan dari kalangan umat Islam untuk menerapkan syariat Islam dalam negara hukum Indonesia. Untuk kesekian kalinya pula, kalangan politisi berdebat panjang menyoal apakah syariat Islam mesti dimasukkan dalam Undang-Undang Dasar 1945 atau tidak. Angin demokrasi yang berjalan di era refor-

30 Achmad Sanusi, Pengantar Ilmu Hukum dan Pengantar Tata Hukum Indonesia (Bandung: Universitas. 1957), hlm. 44.

31 Gagasan Cak Nur tentang negara hukum merujuk kepada sistem pemerintahan demokrasi liberal yang menerapkan pemisahaan kekuasaan negara, seperti juga diungkapkan oleh John Locke bahwa negara harus memegang kewajiban-kewajiban dalam bentuk: (a) kekuasaan legislatif tidak boleh digunakan untuk mengatur nasib rakyat secara sembarangan; (b) kekuasaan negara tidak boleh dijalankan tanpa pertimbangan yang matang; (c) pemerintah tidak boleh mengambil atau merampas hak milik rakyat tanpa persetujuan; dan (d) perundang-undangan harus menjamin agar kekuasaan politik digunakan bagi kepentingan umum akan terealisasi dalam koridor NKRI.

32 Lihat Kusnu Goesniadhie, Perkembangan Konsep Negara Hukum, artikel dalam http://kgsc.wordpress.com/2009/07/11/perkembangan-konsep-negarahukum/, diakses tanggal 18 November 2011. 
masi tampaknya berbeda jauh dengan di masa Orde Lama ketika Majelis Konstituante tahun 1955 mengalami deadlock menyoal bunyi sila kesatu dalam Pancasila. Umat Islam dan seluruh rakyat Indonesia di tahun 1999 sudah cukup dewasa dalam menerima nilainilai demokrasi, bahwa Pancasila adalah sesuatu yang final dan tidak perlu diusik sebagai landasan ideologi negara.

Tuntutan mendasar adalah adanya otonomi bagi penerapan syariat Islam di berbagai daerah yang menghendakinya. Misalnya, masyarakat muslim di Nangroe Aceh Darussalam (NAD) menghendaki adanya UndangUndang Otonomi Khusus Penerapan Syariat Islam di Aceh. Di satu sisi, bagi kalangan proIslam tuntutan ini menjadi "spirit baru" demokrasi, di mana masyarakat muslim bisa menerapkan syariat Islam. Tapi di sisi lain, ada kekhawatiran nilai-nilai demokrasi dan hak asasi manusia akan terserabut akibat dari formalisasi syariah di daerah otonomi khusus tersebut. Sehingga memunculkan adagium bahwa "kembali ke syariah adalah kemunduran demokrasi di Indonesia".

Untuk menjelaskan reformasi syariah dalam konteks negara hukum Indonesia dan terutama di era reformasi, peneliti mencoba untuk membandingkan pandangan Cak Nur dengan 'Abdullah Ahmad al-Nâ'im. Menurut al-Nâ'im, ${ }^{33}$ syariah hanya bisa dijalankan secara sukarela oleh penganutnya. Sebaliknya, prinsip-prinsip syariah akan kehilangan otoritas dan nilai agamanya apabila dipaksakan oleh negara. Pemisahan Islam dan negara secara kelembagaan sangat diperlukan agar syariah bisa berperan positif dan mencerahkan bagi kehidupan umat dan masyarakat Islam.

Pendapat al-Nâ'im di atas, disebut juga netralitas negara terhadap agama, di mana institusi negara tidak boleh memihak kepada doktrin atau prinsip agama manapun. Walau bagaimanapun juga, netralitas seperti itu sasarannya adalah semata-mata kebebasan individu dalam masyarakat untuk mendu-

33 Peneliti mengutip tulisan Deni K. Yusup, Islam, Negara dan Konstitusionalisasi Syari'ah: Review atas Pemikiran Abdullahi Ahmed al-Nấim tentang Masa Depan Syariah (Sekularisme dalam Perspektif Islam), PPS UIN SGD Bandung 2007. kung, berkeberatan, atau memodifikasi setiap pandangan atas doktrin atau prinsipprinsip agama. Namun pendapat al-Nâ‘im ini bukan berarti bahwa Islam dan politik harus dipisahkan, sebab hal tersebut tidak perlu dan tidak dikehendaki.

Pemisahan Islam dan negara, menurut al-Nâ'im tetap mempertahankan hubungan antara Islam dan politik, memungkinkan penerapan bagi prinsip-prinsip syariat Islam dalam kebijakan dan perundang-undangan resmi, tetapi dengan tetap tunduk kepada perisai-perisai hukum, yang akan dijelaskan di bawah ini. ${ }^{34}$ Pandangan ini berangkat dari premis bahwa negara dan politik sulit dibedakan, meskipun di antara keduanya terdapat hubungan yang permanen dan nyata. Dengan kata lain, al-Nâ‘im tampaknya lebih memilih melakukan mediasi strategis dan terencana terhadap ketegangan pemisahan agama dan negara serta mengatur hubungan Islam dan politik, daripada mencoba memaksakan suatu penyelesaian yang tuntas dengan berbagai cara.

Jika mengacu kepada pandangan Cak Nur tentang relasi agama dan negara, maka al-Nâ'im tampaknya terlalu mempetakan negara sebagai suatu jaringan yang rumit dari organ-organ, institusi-institusi, dan prosesproses, yang semestinya bisa menerapkan kebijakan-kebijakan yang diambil melalui proses politik dari setiap masyarakat. ${ }^{35}$ Dengan pengertian ini negara seharusnya merupakan segi swakelola pemerintahan yang dijalankan secara lebih mantap dan terencana, sedangkan politik adalah proses dinamis da-

34 Ibid.

35 Bandingkan dengan pandangan Cak Nur yang menjelaskan bahwa pembaharuan poltik di Indonesia hendaknya difokuskan pada tiga hal, yaitu pentingnya oposisi, civil society dan pancasila sebagai ideologi terbuka. Cak Nur mengatakan agar adanya keseimbangan antara partai penguasa dan partai sengai oposisi. Cak Nur menyebutnya dengan "memompa ban kempes", maksudnya adalah Cak Nur mendukung partai oposisi yang memiliki kekuatan dan menjadi kontrol bagi partai penguasa agar terciptanya kesimbangan politik yang baik dan sehat. Pada era orde baru dikenal istilah 3M (militer, mesin birokrasi, money) yang mendukung Orde Baru di masa kejayaannya. Lihat dalam pandangan Cak Nur yang dikuitp oleh Gaud A. F. Ahmad, Nurcholish Madjid: Jalan Hidup Seorang Visioner (Jakarta: Kompas. 2010), hlm. 258-259. 
lam memilih diantara pilihan-pilihan kebijakan yang saling berlawanan.

Untuk menjalankan fungsi tersebut dan yang lainnya, negara harus memiliki apa yang disebut monopoli penggunaan kekuatan yang sah, yaitu kemampuan untuk memaksakan kehendaknya pada seluruh penduduk tanpa risiko menghadapi perlawanan yang dilakukan rakyat di bawah kekuasaannya. Kekuatan memaksa negara, yang kini makin meluas dan efektif dibanding yang pernah ada dalam sejarah kehidupan manusia, akan menjadi kontra-produktif ketika dijalankan dengan sewenang-wenang atau untuk tujuan-tujuan yang korup dan tidak sah. Itulah mengapa sangat penting untuk tetap menjaga negara senetral mungkin.

Menurut pandangan Cak Nur, tugas tersebut menuntut kewaspadaan yang kokoh dari semua warga negara yang bertindak melalui berbagai strategi dan mekanisme politik, hukum, pendidikan, dan lainnya. Oleh karena itu, al-Nâ'im berpendapat bahwa pembedaan antara negara dan politik mengasumsikan adanya interaksi yang ajek di antara organ-organ dan institusi-institusi negara, di satu sisi, dan aktor-aktor politik dan sosial yang terorganisir, serta pandanganpandangan yang berlawanan tentang kemaslahatan publik, di sisi lain. ${ }^{36}$ Pembedaan ini juga beranjak dari suatu kesadaran yang serius akan risiko penyalahgunaan kekuatan negara yang memang memaksa.

Al-Nâ'im juga menegaskan bahwa sangat penting untuk memastikan bahwa negara bukan sekadar sebuah pencerminan penuh dari politik sehari-hari, melainkan harus mampu menengahi dan menjatuhkan keputusan atas pandangan-pandangan dan proposal-proposal kebijakan yang bertentangan, yang menuntut independensi dari kekuatankekuatan politik yang berbeda dalam masyarakat. ${ }^{37}$ Karena independensi sepenuhnya tidaklah mungkin, maka kadang perlu untuk mengingat kembali hakikat politik negara yang tidak bisa sepenuhnya otonom dari aktor-aktor politik yang mengontrol aparaturnya. Namun sisi paradoksnya terletak pada realitas keterhubungan ini justru menun- tut usaha keras untuk memisahkan negara dari politik, agar orang-orang yang kini disingkirkan dari proses politik masih bisa mengharapkan perlindungan organ-organ dan institusi-institusi negara terhadap eksesekses dan penyalahgunaan kekuasaan oleh pejabat-pejabat pemerintahanan dan negara.

Dalam pandangan Cak Nur, ${ }^{38}$ kegagalan menjalankan pembedaan antara negara dan politik cenderung membahayakan perdamaian, stabilitas dan perkembangan yang sehat dari seluruh masyarakat. Pasalnya, mereka yang terabaikan haknya untuk memperoleh pelayanan dan perlindungan negara serta berpartisipasi aktif dalam politik akan menarik diri atau terpaksa menempuh jalur kekerasan karena tidak adanya cara-cara penanggulangan yang memadai. Oleh karena itu, pertanyaan kemudian adalah bagaimana mempertahankan pembedaan negara dan politik, ketimbang mengabaikan ketegangan tersebut dengan harapan bahwa ketegangan itu akan teratasi dengan sendirinya. Pembedaan negara dan politik yang perlu namun sulit ini dapat dimediasikan melalui prinsipprinsip dan mekanisme-mekanisme yang menjaga dan mendukung konstitusionalisme serta kesetaraan hak-hak seluruh warga negara sesuai dengan prinsip-prinsip hukum Islam dan hak asasi manusia universal.

Pandangan Cak Nur tentang reformasi syariah tampaknya agak mirip dengan pandangan al-Nâ‘im yang mengusung tiga kerangka berfikir sebagai berikut:

Pertama, secara umum dapat diketahui bahwa Islam merupakan agama monoteistik yang disebarkan Nabi Muhammad SAW antara 610-632 Masehi, manakala beliau menyampaikan al-Quran dan menguraikan makna-makna dan berbagai aplikasinya secara terperinci melalui apa yang kemudian dikenal sebagai Sunnah Nabi. ${ }^{39}$ Oleh karena itu, kedua sumber ini, al-Quran dan Sunnah Nabi, merupakan dasar dari pengertian istilah Islam dan konsep-konsep turunan serta ajektiva yang digunakan, khususnya di kalangan umat Islam;
36 Ibid.
37 lbid. 
Kedua, istilah syariah seringkali digunakan dalam wacana Islam saat ini, seolah-olah kata ini sinonim dengan Islam dalam pengertian umum seperti yang dipaparkan di atas. Yakni, sebagai totalitas kewajiban keagamaan umat Islam baik dalam pengertian personal-pribadi, maupun dalam kaitannya dengan norma-norma dan kelembagaan sosial, politik, dan hukum. Namun, prinsip-prinsip syariah selalu merupakan interpretasi manusia atas al-Quran dan al-Sunnah; prinsipprinsip hukum syariah merupakan sesuatu yang dapat dipahami dan coba diamalkan oleh umat manusia dalam konteks sejarah tertentu; dan

Ketiga, sebagai sebuah institusi politik, negara bukanlah sebuah entitas yang bisa merasakan, mempercayai atau bertindak. ${ }^{40}$ Manusialah yang selalu bertindak atas nama negara, menggunakan kekuasaan atau menjalankannya melalui organ-organnya. Jadi kapan pun manusia membuat keputusan tentang persoalan kebijakan, mengusulkan atau membuat rancangan undang-undang yang dianggap mewujudkan prinsip-prinsip Islam, hal ini dengan sendirinya mencer-minkan perspektif pribadi manusia itu atas persoalan tersebut, dan sama sekali bukan perspektif negara sebagai sebuah entitas yang otonom.

Lebih dari itu, ketika usulan kebijakan atau undang-undang seperti itu dibuat atas nama partai politik atau organisasi, posisiposisi seperti itu juga diambil oleh manusia pemimpin yang berbicara atau bertindak untuk entitas itu. Benar bahwa sikap-sikap spesifik pada persoalan-persoalan kebijakan dan perundang-undangan bisa dinegosiasikan di antara aktor-aktor yang kritis, tapi hasilnya tetap saja produk dari penilaian individual seorang manusia, dan pilihan yang diterima dan dilaksanakan pun berdasarkan sebuah pandangan yang disepakati oleh para aktor itu.

Transformasi sikap-sikap umat Islam terhadap hubungan antara Islam, syariah dan negara melibatkan arena tindakan negara, melalui kebijakan-kebijakan pemerintahan bagi pembaruan hukum dan konstitusional untuk memastikan pemisahan Islam dan negara. Juga terdapat domain masyarakat, pada tingkat individual maupun komunal, yang

40 lbid. memiliki sasaran untuk menggabungkan nilai-nilai netralitas negara terhadap agama, konstitusionalisme dan hak asasi manusia, sebagai sesuatu yang konsisten dengan, jika bukan dibutuhkan oleh Islam. Dua dimensi transformasi baik melalui perubahan institusi-institusi resmi maupun melalui perubahan pada tingkat masyarakat sipil, pada kenyataannya saling tergantung dan saling mendukung.

Oleh karena itu, transformasi-transformasi yang dimaksud itu mengakui ragam relevansi Islam terhadap komunitas-komunitas muslim di seluruh permukaan bumi, baik sebagai agama, dan lebih luas lagi, sebagai kebudayaan, maupun sebagai dasar praktik sosial. Ini menunjukkan dimensi ketiga pokok pikiran yang diajukan Cak Nur sebagai jawaban pertanyaan tentang bagaimana mengubah akar sosial dalam kebudayaan atau memberinya legitimasi kultural. Sebagaimana akan ditekankan berulang kali di dalam buku ini, pemisahan Islam dan negara bukan berarti tidak memberikan peran pada Islam dalam kebijakan publik, perundang-undangan atau kehidupan publik secara umum, tapi peran itu harus didukung oleh apa yang saya sebut "nalar publik", dan harus tunduk kepada perisai-perisai konstitusional serta perlindungan hak asasi manusia.

\section{E. Transformasi Norma-norma Syariah ke Dalam Sistem Hukum Nasional}

Dalam pandangan penulis, bagian paling menarik dari pemikiran Cak Nur tentang relasi Islam dan Negara adalah mendiskusikan transformasi norma-norma syariah ke dalam sistem hokum nasional. Dalam banyak karyanya ia menjelaskan dua pesan penting, yaitu:

Pertama, transformasi kebudayaan atau perubahan sosial tidak bisa dijalankan sebagai suatu prakarsa yang murni eksternal, yakni terasing dari sejarah, kebudayaan atau praktik sosial. Sebaliknya, perubahan sosial dan transformasi budaya harus berakar dan berdasar pada budaya komunitas itu sendiri agar supaya perubahan berlangsung absah, koheren dan berkelanjutan. Pada gilirannya hal ini menunjukkan peran penting yang dimainkan komunitas-komunitas dan anggotaanggotanya sebagai partisipan, subyek dan 
aktor perubahan sosial, atau dengan kata lain, peran agensi manusia dalam proses itu. Namun yang perlu dikembangkan adalah berbagai dimensi kerangka kerja tentang bagaimana transformasi sosial ini dalam arti dinamika kebudayaan dan identitas, pentingnya legitimasi kultural diperlukan untuk perubahan sosial, dan peran agensi manusia;

Kedua, menempatkan budayaan sebagai identitas mutlak ditujukan untuk mengembangkan teori yang jelas tentang perubahan sosial diperlukan. Dalam konteks ini, diperlukan suatu pemahaman yang memadai tentang gagasan-gagasan kebudayaan dan identitas, yang merupakan bingkai yang digunakan orang-orang dan komunitas dalam mendefinisikan diri mereka, dan yang menjadi dasar bagi praktik sosial, interaksi, serta pertukaran. Dalam istilah kebudayaan yang paling luas, tercakup totalitas nilai, institusi dan bentuk-bentuk perilaku yang ditransmisikan di dalam masyarakat, termasuk barangbarang serta hubungan-hubungan sosialpolitik;

Ketiga, Legitimasi Kultural Identitas Kebudayaan. Legitimasi kultural bisa didefinisikan sebagai kualitas untuk menyesuaikan diri dengan perinsip-prinsip atau standar-standar umum budaya yang masih dipersoalkan, dengan cara menda-patkan otoritas dan relevansi dari prinsip dan standar budayanya sendiri. Norma atau nilai-nilai yang absah secara kultural adalah norma yang dihormati dan dilaksanakan oleh anggota sebuah komunitas budaya karena norma itu dapat memenuhi beberapa kebutuhan atau tujuan komunitas dan individu yang ada di dalamnya. Karena itu, kesuksesan proses legitimasi kultural ini juga ditentukan oleh pengakuan kita bahwa legitimasi kultural berlaku untuk institusi atau norma yang baru diperkenalkan atau dimodifikasi; dan

Keempat, pemegang otoritas budaya, otoritas dan relevansi perubahan yang diperoleh dari validitas internal adalah penting karena beberapa alasan yang inheren dalam dinamika-dinamika hubungan-hubungan sosial dan interaksi sosial. Masyarakat mungkin menganggap perubahan sebagai sesuatu yang positif dan bermanfaat, tetapi perubahan-perubahan demikian mungkin pada awalnya ditolak sebagai sesuatu yang negatif dan merusak oleh para penjaga tradisi tatanan sebelumnya.

Dengan menerima kenyataan tersebut, maka setiap pihak yang berdebat mampu menyoal bagaimana cara memahami dan menghadapi sudut pandang pihak lain. Selain itu, seorang individu juga boleh jadi akan sangat tergantung kepada masyarakatnya yang mampu untuk menanamkan atau memaksanakan keselarasan pada anggotaanggotanya, kebijakan dan tindakan publik lebih mungkin berjalan seiring dengan norma-norma dan pola-pola perilaku kultural yang ideal dibanding tindakan-tindakan pribadi. Perubahan perilaku publik mungkin membutuhkan waktu yang lama karena individu cenderung menyesuaikan diri setelah norma baru diterima secara luas.

Untuk menghindari kesulitan-kesulitan seperti itu, Cak Nur mengusulkan bahwa alasan bagi semua kebijakan publik dan perundang-undangan harus selalu didasarkan pada nalar publik, seperti yang telah diterangkan di awal. Muslim dan para penganut agama lain harus bisa mengajukan prakarsaprakarsa pembuatan kebijakan publik dan undang-undang yang terpancar dari keyakinan mereka, dengan syarat mereka dapat mendukungnya dalam debat publik, yang bebas dan terbuka dengan alasan-alasan yang dapat diterima dan meyakinkan warga negara secara umum, tanpa memandang agama atau keyakinan mereka.

Untuk membangun kerangka ideal bagi reformasi syariah dalam bingkai negara hukum Indonesia, sekurang-kurangnya ada dua pendekatan. Pertama, Pendekatan Kontekstual terhadap Sekularisme sebagai Mediasi. Kata sekuler dalam bahasa Inggris berasal dari kata Latin saeculum, yang artinya periode besar waktu atau lebih dekat spirit zaman. Belakangan, maknanya berubah menjadi dunia ini, yang secara tak langsung berarti ada lebih dari satu dunia. Istilah ini akhirnya diterjemahkan menjadi konsep "sekuler" dan "religious" yang berasal dari ide temporal dan spiritual. Istilah ini juga berkembang dalam konteks Eropa dari sekularisasi dalam artian privatisasi wilayah-wilayah gereja, hingga sekularisasi politik, dan kemudian seni serta ekonomi.

Garis perkembangan ini tergambar dalam definisi sekularisme di kamus Webster: "Pengabaian atau penolakan atau penga- 
singan agama atau pertimbangan keagamaan". The Short Oxford Dictionary mendefinisikan sekularisme sebagai doktrin bahwa moralitas seharusnya semata-mata didasarkan pada penghargaan atas umat manusia dalam kehidupan seperti sekarang ini, dengan membuang semua pertimbangan yang diambil dari keyakinan pada Tuhan atau hari akhirat. Oleh karena itu, istilah ini sering digunakan untuk menandakan gagasangagasan, seperti kemunduran agama, kesesuaian dengan kehidupan masa kini, pemisahan dan pembedaan masyarakat dari agama (pemisahan gereja dan negara), transposisi keyakinan-keyakinan dan institusiinstitusi agama (beralih dari sumber kekuasaan Tuhan ke sebuah gejala kemampuan dan kreasi manusia), "desakralisasi” dunia dan kemudian "sakralisasi" akal pikiran.

Kemudian dari perspektif sangat kontekstual yang saya kemukakan dalam buku ini, pandangan-pandangan tentang sekularisme yang saya sebutkan tadi sebagian besar merupakan gambaran-gambaran tentang bagaimana konsep ini berkembang di berbagai negara Eropa dan Amerika Utara, masingmasing dengan caranya sendiri-sendiri. Pada kenyataannya, ajaran sekularisme adalah konsep multidimensional yang menggambarkan elemen-elemen lanskap sejarah, politik, sosial dan ekonomi suatu negara. Demikian pula, sekularisme bagi beragam masyarakat muslim hendaknya mempertimbangkan dimensi keagamaan dalam kehidupan komunitas-komunitas lokal, daripada dilihat sebagai usaha untuk memaksakan gagasan-gagasan yang telah terbentuk sebelumnya tentang peminggiran agama ke domain pribadi.

Negara dan berbagai organ dan institusinya dipikirkan dan dijalankan di mana-mana oleh orang-orang yang keyakinan agama dan filosofisnya tercermin dalam pemikiran dan tingkah laku mereka. Namun, elit-elit yang berkuasa tidak bisa memaksakan pandangan agama mereka pada orang lain, meski mereka berusaha melakukannya pasti mereka akan tersandung pada persoalan-persoalan yang serius. Ketegangan di dalam hubunganhubungan ini dan kebutuhan untuk menengahinya seharusnya diakui dan diatur, daripada menuntut hal yang tak mungkin berhasil; pemisahan atau penyatuan total agama dan negara.
Alasan lain pentingnya pemahaman sekularisme menurut Cak Nur sebagai mediasi adalah bahwa membatasi konsep ini pada pemisahan agama dan negara bisa memudahkan bersatunya komunitas-komunitas agama yang beragam ke dalam sebuah komunitas politik, semata-mata karena konsep yang demikian hanya membuat klaim-klaim moral yang rendah atas komunitas dan anggotanya. Boleh jadi benar bahwa sekularisme tidak netral secara moral, karena sekularisme mesti menganjurkan etos kewarganegaraan tertentu untuk mencapai tujuan memisahkan agama dan negara, yang bisa sangat maju dan ketat.

Namun demikian, syarat-syarat moral dan etis konsep tersebut harus tetap rendah guna mencapai dan mempertahankan konsensus di antara tradisi-tradisi agama dan filsafat yang saling berlawanan. Jadi, tuntutan pemisahan yang tegas tanpa memperhitungkan peran publik agama tidaklah realistis dan menyesatkan. Tidak realistis karena ini merupakan pandangan negatif mengenai hubungan agama dan kebijakan publik, menekankan pengasingan etika agama tanpa memberikan alternatif, sehingga gagal mempertimbangkan fondasi-fondasi etis dan moral sebuah kebijakan publik.

Pendekatan yang kedua adalah negara bersifat teritorial dan bukan Islami. Konsekuensi yang tak dapat dielakkan dari interpretasi manusia atas teks-teks Islam, seperti yang telah ditekankan di awal, adalah bahwa pandangan-pandangan alternatif tentang Islam dan formulasi prinsip-prinsip hukum syariah selalu mungkin, dan bisa sama-sama valid jika diterima oleh umat Islam. Karena tidak mungkin mengetahui apakah muslim atau non-muslim akan menerima atau menolak suatu pandangan kecuali pandangan itu diungkapkan dan diperdebatkan secara terbuka dan bebas, sangatlah perlu untuk mempertahankan kebebasan agar opini, keyakinan dan uangkapan keyakinan terus muncul dan tersebar.

Oleh karena itu, ide sensor secara inheren lebih bersifat destruktif dan kontraproduktif bagi perkembangan prinsip dan doktrin Islam; karenanya sangat penting menjaga kemungkinan-kemungkinan perbedaan pendapat sebagai satu-satunya jalan agar tradisi tetap responsif terhadap kebu- 
tuhan para penganutnya. Seperti yang nantinya diterangkan dan didiskusikan pada babbab selanjutnya, ruang yang diperlukan untuk perbedaan pendapat dan perdebatan itu saat ini diamankan dengan sangat baik melalui pemerintahan demokratis yang konstitusional dan perlindungan hak-hak asasi manusia.

Demikian halnya, konsep-konsep modern dan institusi-institusi yang digunakan untuk implementasinya tidak hanya perlu bagi kebebasan beragama warga negara muslim dan non muslim di negara teritorial saat ini, tapi juga untuk mempertahankan dan mengembangkan Islam itu sendiri. Karena kebebasan untuk berbeda pendapat dan perdebatan adalah hal yang essensial bagi perkembangan syariah itu sendiri, karena hal itu akan memberi kemungkinan bagi berkembangnya konsensus secara bebas di seputar pandangan tertentu, yang menjadi matang dalam prinsip-prinsip yang mapan melalui penerimaan dan praktik oleh generasi-generasi Muslim dalam berragam situasi yang melingkupinya.

Argumen di atas seolah-olah mengandung pengertian bahwa barangsiapa yang dianggap kafir oleh standar-standar syariah sama sekali tidak diizinkan hidup di dalam wilayah negara tersebut kecuali di bawah hubungan aman sementara (aman). Gagasan-gagasan demikian sekarang sangat jelas tak dapat dipertahankan secara moral dan politis, bahkan pendukung-pendukung negara Islam yang paling bersemangat pun tidak mendiskusikan penerapan gagasan itu dalam realitas-realitas negara-negara teritorial yang pluralis sekarang ini yang secara total terintegrasi ke dalam sistem ekonomi, politik dan hukum internasional.

Mengacu kepada perspektif tersebut di atas, Cak Nur ingin menegaskan bahwa ia menentang ide negara Islam yang menjadikan syariah sebagai hukum positif dan kebijakan resmi negara, karena alasan-alasan yang sudah diringkas di awal dan akan dibahas selanjutnya. Jika klaim-klaim itu benar, negara seperti itu akan diwajibkan mengimplementasikan prinsip-prinsip syariah tradisional seperti sistem dzimmah yang tidak mungkin bisa menerima non muslim menjadi warga negara. Ide dasar dari sistem ini adalah bahwa setelah penaklukan dan penya- tuan wilayah-wilayah baru melalui jihad, Ahli Kitab (terutama Kristen dan Yahudi) harus diperbolehkan tinggal di sana sebagai komunitas yang dilindungi karena mereka tunduk kepada kedaulatan Islam, tapi mereka tidak bisa menikmati persamaan dengan umat Islam.

\section{F. Penutup}

Setelah menyimak pemaparan di atas, penulis dapat merumuskan bahwa Cak Nur melihat ada peluang yang lebih luas untuk membentuk sistem pemerintahan Islam, namun pengembangan gagasan reformasi syariah di Indonesia harus memperhatikan pertimbangan sebagai berikut: pertama, umat manusia cenderung mencoba dan mengalami tipe-tipe dan bentuk-bentuk ganda dan tumpang tindih keanggotaan dalam kelompok-kelompok yang berbeda berdasarkan etnis, identitas keagamaan atau kultural, afiliasi profesional, sosial atau politik, kepentingan ekonomi dan seterusnya; kedua, makna dan implikasi-implikasi setiap tipe atau bentuk keanggotaan seharusnya ditentukan oleh dasar pemikiran atau tujuan untuk menjadi anggota kelompok dimaksud, tanpa menghalangi atau memperlemah efektifitas bentuk keanggotaan lainnya. Keanggotaankeanggotaan ganda dan juga tumpang tindih seharusnya tidak saling terpisah satu sama lain, kendati cenderung mencapai tujuan-tujuan yang berbeda bagi orang-orang dan komunitas-komunitas; dan ketiga, istilah kewarganegaraan yang digunakan mengacu kepada bentuk khusus status keanggotaan dalam komunitas politik negara teritorial dalam konteks globalnya.

Selain itu, pandangan positif tersebut hendaknya dihubungkan dengan adanya dasar pemikiran atau tujuan spesifik tanpa menghalangi kemungkinan persamaan status. Pandangan-pandangan positif yang dikemukan oleh Cak Nur sekurang-kurangnya telah mewakili gagasan reformasi syariah dalam bingkai negara hukum berdasarkan pengalaman di masa lalu, masa kini, dan masa depan. Namun penting untuk dicermati di sini, peneliti melihat bahwa gagasan reformasi syariah yang bamyak diusung kalangan pemikir muslim selalu saja berbenturan dengan berbagai dimensi politik di ranah politik 
hukum. Bukan hanya terkadang rumit dibicarakan di area publik, bahkan di ranah teoritis pun hal ini menjadi bias dengan tingkat pemahaman subyektifitas kecenderungan setiap pemikir.

Penulis juga mengambil beberapa pokok pikiran dari pemikiran Cak Nur tentang reformasi syariah dalam konteks dialektika politik hukum Islam di Indonesia sebagai berikut: Pertama, pengembangan pemikiran tentang negara hukum dan reformasi syariah berikut implikasi-implikasinya hendaknya lebih berorientasi kepada masa depan demokrasi itu sendiri; Kedua, reformasi syariah hendaknya bukan hanya dibicarakan pada dataran ide yang tidak membumi, tetapi mesti diarahkan kepada masalah yang bisa diaplikasikan sesuai dengan realitas kehidupan masyarakat saat ini dan di masa depan; dan Ketiga, pemikiran manusia akan selalu berdialektis sesuai dengan perubahan zamannya, dan karena Islam tidak memberikan format ideal tentang negara, maka negara hukum yang Islami sepenuhnya diserahkan menjadi pilihan manusia itu sendiri (antum a'lamu bi umûri dunyâkum).

\section{Daftar Pustaka}

Ahmad, Gaud A. F. 2010. Nurcholish Madjid: Jalan Hidup Seorang Visioner. Jakarta: Kompas.

Atmosudirjo, Prajudi. 1995. Hukum Administrasi Negara. Jakarta: Ghalia Indonesia.

Hadjon, Philipus M. 1972. Perlindungan Hukum Bagi Rakyat di Indonesia: Sebuah Studi tentang Prinsip-prinsipnya, Penerapannya oleh Pengadilan dalam Lingkungan Peradilan Umum dan Pembentukan Peradilan Administrasi Negara. Surabaya: Bina Ilmu.

Huijber, Theo. 1995. Filsafat Hukum dalam Lintasan Sejarah. Yogyakarta: Kanisius.

Kusnardi, Moh. dan Harmaily Ibrahim. 1988. Pengantar Hukum Tata Negara Indonesia. Jakarta: PSHTN FH UI dan Sinar Bakti.
Kusumohamidjojo, Budiono. 2004. Filsafat Hukum: Problemtika Ketertiban yang Adil. Jakarta: Grasindo.

Madjid, Nurcholish. 1998. Dialog Keterbukaan: Artikulasi Nilai Islam dalam Wacana Sosial Politik Kontemporer. Jakarta: Paramadina.

Madjid, Nurcholish. 1999. Masyarakat Madani dan Investasi Demokrasi: Tantangan dan Kemungkinan. Bandung: Pustaka Hidayah.

Madjid, Nurcholish. 2000. Puasa Titian Menuju Rayyan. Yogyakarta: Pustaka Pelajar.

Madjid, Nurcholish. 2001. Agama dan Politik dalam Islam. Yogyakarta: Pustaka Pelajar.

Malian, Sobirin. 2001. Gagasan Perlunya Konstitusi Baru Pengganti UUD 1945. Yogyakarta: FH UII Press.

Marbun, S. F. 2001. Dimensi-dimensi Pemikiran Hukum Administrasi Negara. Yogyakarta: UII Press.

Marbun, S. F. Dkk. 2001. Dimensi-dimensi Pemikiran Hukum Administrasi Negara. Yogyakarta: UII Press.

Ricci, Luigi dan E.R.P. Vincent. 1955. a Mentor Book, The New Amer Oan Library: Cristian Gans - A Mentor book. USA: The New American Library.

Sabaroedin, Tb (Penerjemah). 1955. Ilmu Negara Umum. Jakarta: J.B. WoltersGroningen.

Sanusi, Achmad. 1957. Pengantar Ilmu Hukum dan Pengantar Tata Hukum Indonesia. Bandung: Universitas.

Schmidel, J. J. Von. 1988. Pemikiran tentang Negara dan Hukum. Jakarta: Pembangunan.

Shiddiqie, Jimly as-. 1994. Gagasan Kedaulatan Rakyat dalam Konstitusi dan Pelaksanaannya di Indonesia. Jakarta: Ichtiar Baru van Hoeve.

Shiddiqie, Jimly as-. 2005. Konstitusi dan Konstitusionalisme Indonesia. Jakarta: Konstitusi Press.

Sufyanto. 2001. Masyarakat Tamaddun. Yogyakarta: Pustaka Pelajar.

Thohari, A. Ahsin. 2004. Komisi Yudisial dan Reformasi Peradilan. Jakarta: Elsam. 